\title{
Differential Effects of Cytolytic T Cell Subsets on Intracellular Infection
}

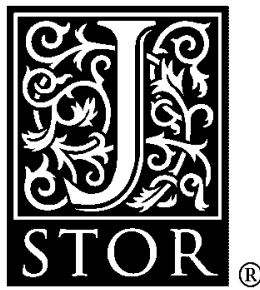

Steffen Stenger; Richard J. Mazzaccaro; Koichi Uyemura; Sungae Cho; Peter F. Barnes; Jean-Pierre Rosat; Alessandro Sette; Michael B. Brenner; Steven A. Porcelli; Barry R. Bloom; Robert L. Modlin

Science, New Series, Vol. 276, No. 5319. (Jun. 13, 1997), pp. 1684-1687.

Stable URL:

http://links.jstor.org/sici?sici=0036-8075\%2819970613\%293\%3A276\%3A5319\%3C1684\%3ADEOCTC\%3E2.0.CO\%3B2-8

Science is currently published by American Association for the Advancement of Science.

Your use of the JSTOR archive indicates your acceptance of JSTOR's Terms and Conditions of Use, available at http://www.jstor.org/about/terms.html. JSTOR's Terms and Conditions of Use provides, in part, that unless you have obtained prior permission, you may not download an entire issue of a journal or multiple copies of articles, and you may use content in the JSTOR archive only for your personal, non-commercial use.

Please contact the publisher regarding any further use of this work. Publisher contact information may be obtained at http://www.jstor.org/journals/aaas.html.

Each copy of any part of a JSTOR transmission must contain the same copyright notice that appears on the screen or printed page of such transmission.

The JSTOR Archive is a trusted digital repository providing for long-term preservation and access to leading academic journals and scholarly literature from around the world. The Archive is supported by libraries, scholarly societies, publishers, and foundations. It is an initiative of JSTOR, a not-for-profit organization with a mission to help the scholarly community take advantage of advances in technology. For more information regarding JSTOR, please contact support@ jstor.org. 
$\mathrm{ICl}$ and eject an I atom back to the gas phase (Cl-selective abstraction) despite the much larger exothermicity for the formation of $\mathrm{Si}-\mathrm{Cl}(\mathrm{s})+\mathrm{I}$ than $\mathrm{Si}-\mathrm{I}(\mathrm{s})+\mathrm{Cl}$.

The reorientation by the surface would also explain the higher abstraction ratio for $\mathrm{ICl}$ over that for $\mathrm{Br}_{2}$. An end-on geometry has been calculated to favor abstraction over dissociation for halogens on semiconductor and metal surfaces because this geometry places the terminal halogen far from the surface in an optimal position for abstraction $(2,11)$. Although molecules in the molecular beam usually have a nearly side-on or tilted orientation, reorientation by the surface should place a large fraction of the $\mathrm{ICl}$ into an end-on geometry and thus increase abstraction.

We propose that the orientation of $\mathrm{ICl}$ into I-end-first configuration results from the higher polarizability of I compared to $\mathrm{Cl}$ and the asymmetric molecular bonding associated with $\mathrm{ICl}$. Because $\mathrm{Cl}$ is much more electronegative than $\mathrm{I}$, the bonding $\sigma_{z}$ and $\pi_{r . y}$ orbitals predominantly consist of $\mathrm{Cl}^{2} \mathrm{pp}$ orbitals, whereas the antibonding $\sigma_{z}^{*}$ and $\pi_{x, y} *$ orbitals predominantly consist of I $5 p$ orbitals. The highest occupied molecular orbital $(\mathrm{HOMO})$ is mainly concentrated at the I atom of an ICl molecule; thus, the I end is both more polarizable and more reactive than the $\mathrm{Cl}$ end. This difference was confirmed by Hartree-Fock molecular orbital calculations made using the SpartanPlus program (12) which show that the effective radius of the $\pi^{*}$-orbital wave function is $70 \%$ greater on the I atom than on the $\mathrm{Cl}$ atom. Conversely, there is only $10 \%$ difference in the effective radius of the probability density of the entire valence shell between the I and the $\mathrm{Cl}$ atoms. Therefore, we suggest that when an $\mathrm{ICl}$ molecule approaches a $\mathrm{Si}$ adatom on the $\mathrm{Si}(111)-(7 \times$ 7) surface, the interaction of an $\mathrm{ICl} \pi_{x, y} *$ antibond (HOMO) with the partially filled Si dangling bond results in greater attraction to the I end than the $\mathrm{Cl}$ end of the $\mathrm{ICl}$ molecule. This selection is the driving force for the I-end-first orientation of $\mathrm{ICl}$ before reaction and ultimately causes chemical selectivity for the reaction of $\mathrm{ICl}$ with the Si(111)- $(7 \times 7)$ surface. This same molecular-orbital argument was used to explain the chemical selectivity of the $\mathrm{D}+\mathrm{ICl} \rightarrow \mathrm{DI}+$ $\mathrm{Cl}$ gas-phase reaction (1). Reorientation of $\mathrm{NO}$ (13) by $\mathrm{Ag}(111)$ or $\mathrm{Pt}(111)$ and of $\mathrm{H}_{2}$ by $\mathrm{W}(100)(14)$ or $\mathrm{Pd}(100)(15)$ is denoted as rotational steering and has been observed in theoretical simulations. Therefore, the reorientation of molecules by surfaces may be a general phenomenon and is probably the dynamic mechanism responsible for this example of atomically selective chemisorption, the selective abstraction of I from ICl by $\mathrm{Si}(111)-(7 \times 7)$.

\section{REFERENCES AND NOTES}

1. J. C. McDonald, P. R. LeBreton, Y. T. Lee, D. R Herschback, J. Chem. Phys. 56, 769 (1972)

2. L. E. Carter, S. Khodabanedeh, P. C. Weakliem, E. A. Carter, ibid. 100, 2277 (1994).

3. Y. L. Li et al., Phys. Rev. Lett. 74, 2603 (1995).

4. K. Takayanagi, Y. Tanishiro, M. Takahashi, S. Takahashi, J. Vac. Sci. Technol. A 3, 1502 (1985).

5. D. Purdie et al. , J. Phys. 3, 7751 (1991); J. J. Bolland and J. S. Villarrubia, Phys. Rev. B. 41, 9865 (1990).

6. J. A. Jensen, C. Yan, A. C. Kummel, Science 267, 493 (1995)

7. C. Yan, J. A. Jensen, A. C. Kummel, J. Chem. Phys. 102, 3381 (1995).

8. J. A. Jensen, C. Yan, A. C. Kummel, Phys. Rev. Lett. 76, 1388 (1996).

9. P. W. Palmberg, G. E. Riach, R. E. Weber, N. C. MacDonald, Handbook of Auger Electron Spectroscopy (Physical Electronics, Edina, MN, 1972).
10. D. A. King and M. G. Wells, Surf. Sci. 29, 454 (1972).

11. J. Stromquist, L. Hellberg, B. Kasemo, B. I. Lundqvist, ibid. 352, 435 (1996)

12. SpartanPlus; Wavefunction, Irvine, CA

13. C. W. Mulhausen, L. R. Williams, J. C. Tully, J. Chem. Phys. 83, 2594 (1985); D. Lemoine, ibid. 101, 4350 (1994); B. Pouilly, J. M. Roobe, D. Lemoine, J. Phys. Condens. Matter 6, 9689 (1994).

14. M. Kay, G. R. Darling, S. Holloway, J. A. White, D. M. Bird, Chem. Phys. Lett. 245, 311 (1995).

15. A. Gross, S. Wilke, M. Scheffler, Phys. Rev. Lett. 75 , 2718 (1995).

16. We thank NSF (grant DMR-9307259) and the U.S. Air Force Office of Scientific Research (grant 94-10075) for funding this work, A. Komrowski and K. Pettus for helpful assistance in the experiments, and P. Taylor of the Univ. of Califomia at San Diego Supercomputer Center for performing the molecular orbital calculations.

19 February 1997; accepted 11 April 1997

\title{
Differential Effects of Cytolytic T Cell Subsets on Intracellular Infection
}

\author{
Steffen Stenger, Richard J. Mazzaccaro, Koichi Uyemura, \\ Sungae Cho, Peter F. Barnes, Jean-Pierre Rosat, \\ Alessandro Sette, Michael B. Brenner, Steven A. Porcelli, \\ Barry R. Bloom, Robert L. Modlin*
}

In analyzing mechanisms of protection against intracellular infections, a series of human CD1-restricted $T$ cell lines of two distinct phenotypes were derived. Both $C D 4^{-} \mathrm{CD}^{-}$ (double-negative) $\mathrm{T}$ cells and $\mathrm{CD}^{+} \mathrm{T}$ cells efficiently lysed macrophages infected with Mycobacterium tuberculosis. The cytotoxicity of $\mathrm{CD} 4^{-} \mathrm{CD} 8^{-} \mathrm{T}$ cells was mediated by Fas-FasL interaction and had no effect on the viability of the mycobacteria. The CD8 ${ }^{+}$ $T$ cells lysed infected macrophages by a Fas-independent, granule-dependent mechanism that resulted in killing of bacteria. These data indicate that two phenotypically distinct subsets of human cytolytic $T$ lymphocytes use different mechanisms to kill infected cells and contribute in different ways to host defense against intracellular infection.

Effective immunity to intracellular bacterial infection often requires the lysis of infected cells as well as killing of the invading pathogen. A possible role for cytolytic $T$ lymphocytes (CTLs) in protection against M. tuberculosis has been suggested by experiments in mice bearing a disruption in the $\beta_{2}$-microglobulin gene. These mice are unable to express major histocompatibility

S. Stenger, K. Uyemura, S. Cho, R. L. Modlin, Division of Dermatology and Department of Microbiology and Immunology, University of California Los Angeles School of Medicine, Los Angeles, CA 90095, USA

R. J. Mazzaccaro and B. R. Bloom, Howard Hughes Medical Institute, Albert Einstein College of Medicine, Bronx, NY 10461, USA.

P. F. Barnes, Department of Medicine, University of Southern California School of Medicine, Los Angeles, CA 90033, USA.

J.-P. Rosat, M. B. Brenner, S. A. Porcelli, Department of Rheumatology and Immunology, Brigham and Women's Hospital, Boston, MA 02115, USA.

A. Sette, Department of Immunology, Cytel Corporation, San Diego, CA 92121, USA.

To whom correspondence should be addressed. E-mail: rmodlin@medicine.medsch.ucla.edu complex (MHC) class I or class I-like molecules or to generate CTLs and were shown to be highly susceptible to infection (1). Despite numerous studies of $\mathrm{CD}^{+}{ }^{+} \mathrm{T}$ cell responses and cytokine production in tuberculosis, there remain only a few reports of $\mathrm{CD} 8^{+}$CTLs that recognize mycobacterial antigens (2). This paradox led us to investigate whether other antigen-presenting systems could be essential for generation of $M$. tuberculosis-specific CTLs. CD1 is an MHC-like surface molecule with a unique ability to process and present nonpeptide antigens to $T$ cells, including mycobacterial lipids $(3,4)$. We examined whether CD1-restricted CTLs have the capacity to recognize and lyse M. tuberculosis-infected macrophages.

CD1-restricted $\mathrm{T}$ cells were derived from patients with active tuberculosis as well as healthy donors (5). All of these T cell lines recognized $M$. tuberculosis lipid and lipoglycan antigens in a CD1b-restricted manner as assessed by antigen- 
specific $\mathrm{T}$ cell proliferation and interferon- $\gamma($ IFN- $\gamma)$ secretion. T cells were either $\mathrm{CD}^{-} \mathrm{CD}^{-}$(double negative, $\mathrm{DN}$ ) or $\mathrm{CD}^{+}$and expressed $\alpha \beta$ T cell receptors, consistent with our previous findings $(3,4,6)$. We investigated whether CD1restricted $T$ cells recognized antigen-presenting cells (APCs) harboring live mycobacteria. $\mathrm{CD}^{+}$macrophages were infected with virulent M. tuberculosis with $90 \%$ efficiency, such that there were approximately three bacteria per macrophage (7). All DN and CD8 ${ }^{+} \mathrm{T}$ cell lines examined efficiently lysed infected macrophages in a dose-dependent manner (Fig. 1A). The restriction and specificity were shown by the inhibition of CTL-mediated lysis of infected targets and release of IFN- $\boldsymbol{\gamma}$ by antibody to CD1b (Fig. 1B). CTLs did not lyse uninfected $\mathrm{CD} 1^{+}$macrophages.

CTLs lyse targets by two pathways, the exocytosis of granules containing perforin and granzymes and the interaction of Fas ligand on the CTL with Fas on the target cell (8). The mechanisms operate independently: For example, mice with a disrupted perforin gene retain the ability to exert Fas-FasL-dependent $T$ cell lysis, but the biological roles and contribution to immunity of each remains unresolved. Because M. tuberculosis-infected macrophages were killed by two phenotypic sub- sets of cytotoxic $\mathrm{T}$ cells, we sought to clarify the mechanisms of lysis, specifically the relative importance of killing by FasFas $L$ interaction and by the degranulation mechanism. The cytotoxicity mediated by two DN, CD1-restricted CTL lines was markedly inhibited by blocking antibodies to Fas or to FasL (Fig. 2A). In contrast, the cytotoxicity of two CD8 ${ }^{+} \mathrm{CD} 1$-restricted CTL lines was not affected by blocking of Fas or FasL (Fig. 2B). We also determined the contribution of the granule-dependent pathway to the target cell lysis. Strontium ions $\left(\mathrm{Sr}^{2+}\right)$, which release histamine from mast cells by inducing granular degranulation, also induce degranulation of cytotoxic lymphocytes (9), thereby transiently inhibiting lytic activity. This effect was used to determine the extent to which the granule-dependent pathway participated in killing $M$. tuberculosis-infected macrophages (10). Preincubation with $\mathrm{Sr}^{2+}$ selectively inhibited the cytotoxicity of the $\mathrm{CD}^{+}$, but not DN, CD1-restricted CTLs (Fig. 2, A and B). Granzyme A, characteristic of cytotoxic granules, was detected in $\mathrm{Sr}^{2+}$-induced supernatants of $\mathrm{CD}^{+}$, but not DN, T cells (Fig. 2C). The capacity of lymphocytes to proliferate and release IFN- $\gamma$ upon antigen-specific activation was not affected by treatment with
$\mathrm{Sr}^{2+}(11)$. The differential ability of antibodies to Fas-FasL or of $\mathrm{Sr}^{2+}$ to inhibit CTL activity was not dependent on the level of killing (Fig. 2, A and B).

A critical component of lymphocyte cytotoxic granules is perforin, which polymerizes on the target cell membrane after antigen activation and induces a nonselective pore that may be responsible for target cell lysis (12). Using reverse transcriptase-polymerase chain reaction (RT-PCR), we detected induction of perforin mRNA in all three CD8 ${ }^{+}$CTL lines examined, but not in three DN CTL lines (Fig. 2D). In contrast, mRNA for FasL was detected in stimulated DN CTL lines but not in the $\mathrm{CD}^{+}$ lines.

The existence of two populations of human CTLs, differentiated by phenotype and by mechanism of cytotoxicity, was confirmed in a larger group of CTLs. Five DN CTL lines independently derived from different donors, all CD1-restricted, killed targets by the Fas-FasL pathway, with little contribution from the granule-dependent mechanism (Fig. 3). Conversely, the cytotoxicity of three CD8 ${ }^{+}$CD1-restricted CTL lines was granule-dependent. In addition, the killing by two classical $\mathrm{CD}^{+} \mathrm{MHC}$ class I-restricted CTL lines specific for influenza peptide was almost

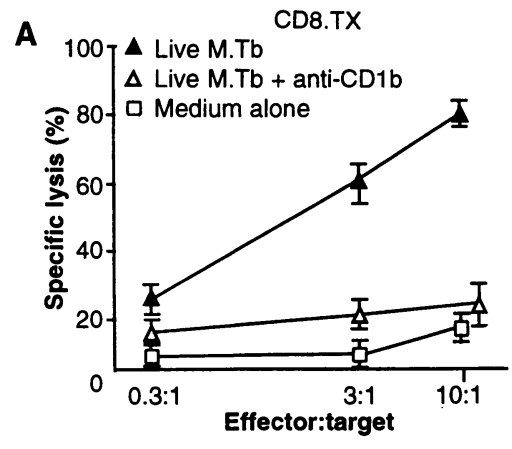

B

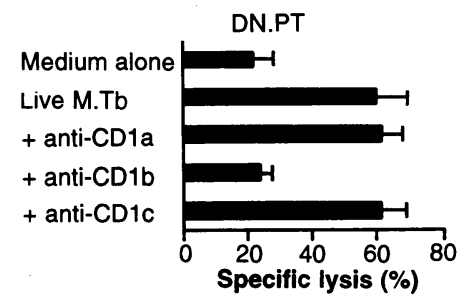

Fig. 1. Cytotoxicity of CD1-restricted CTLS against macrophages infected with virulent $M$. tuberculosis. The cytotoxic response of $(\mathbf{A}) \mathrm{CD}^{+}$ line (CD8.TX) and (B) DN line (DN.PT, E:T = 10:1) against infected macrophages was measured in a ${ }^{51} \mathrm{Cr}$-release assay in the presence or absence of blocking antibodies to CD1 (anti-CD1) (24). The results shown are representative of one out of three independent experiments, each performed in triplicate. Error bars correspond to the SEM.
Fig. 2. Distinct mechanisms of cytotoxicity of DN and $\mathrm{CD}^{+}$CTLs. Cytotoxicity of (A) DN (DN.PB and DN.OR) or (B) $\mathrm{CD}^{+}$ (CD8.TX and CD8.1) CTLs against antigenpulsed macrophages was determined in the presence or absence of blocking antibodies to FasL (5 $\mu \mathrm{g} / \mathrm{ml})$ or Fas $(1 \mu \mathrm{g} / \mathrm{ml})$ or after initial treatment of the CTLs with $\mathrm{Sr}^{2+}$ (25). The E:T ratio was 10:1. The result shown is representative of three independent experiments. Error bars correspond to the SD. (C) Release of BLTesterase by CD1-restricted CTLs induced by treatment with $\mathrm{Sr}^{2+}(26)$. The data shown are representative of three independent experiments, each performed in triplicate. Data are given as the absorbance at $405 \mathrm{~nm} \pm \mathrm{SD}$. (D) Expression of FasL and perforin mRNA by DN and CD8 ${ }^{+}$CTLs. CTLs $\left(2 \times 10^{5}\right)$ were stimulated with antigen for 12 hours, and total RNA was isolated as described (27). cDNA was synthesized and standardized to yield similar amounts of CD38 PCR product within the linear range of amplification. CDNA specific for FasL (28) and perforin (29) was amplified by PCR and visualized by autoradiography (28). Lane 1: DN.OR; lane 2: DN1 lane 3: DN.LDN4; lane 4: CD8.1; lane 5: CD8.2; and lane 6: CD8.FP1.
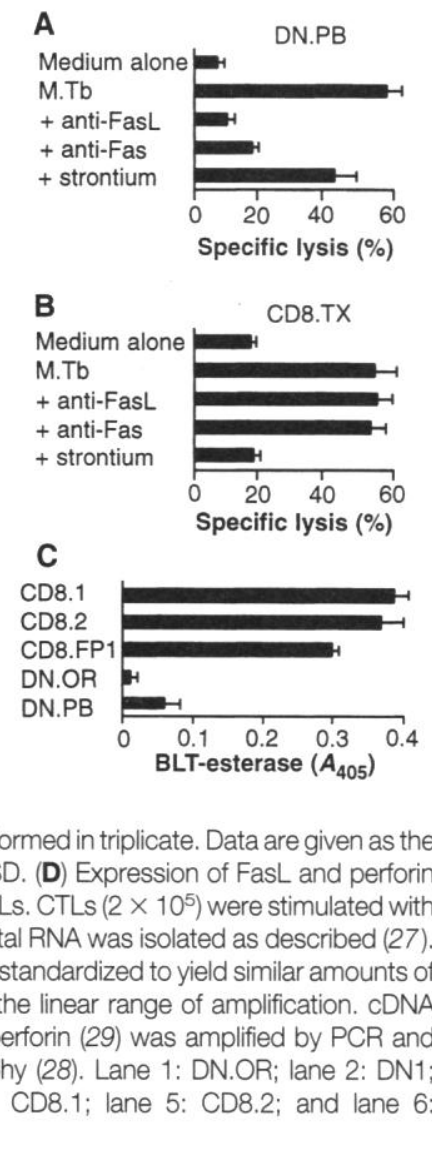
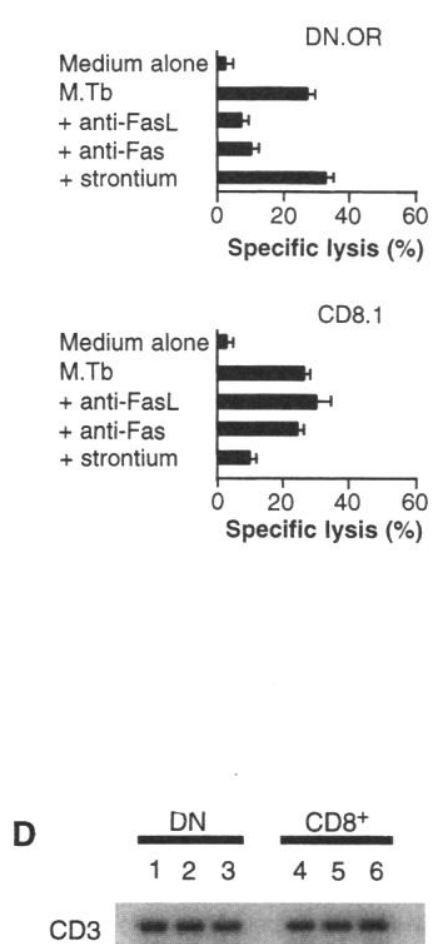

FasL

Perforin 
completely dependent on cytotoxic granules (13).

The question remains as to why the immune response has two virtually independent modes of cytotoxic responses. Lysis of infected macrophages will release intracellular bacteria, thus reducing the reservoir of infected cells. The bacteria will be dispersed and taken up at low multiplicities of infection (MOIs) by activated infiltrating macrophages, which can kill them (14). In addition, the process of lysing the infected target cell may directly or indirectly result in the death of the bacteria. To determine whether CD1-restricted $\mathrm{T}$ cell activation results in killing of intracellular mycobacteria, we cocultured CTL lines with M. tuberculosis-infected $\mathrm{CD} 1^{+}$cells and measured bacterial viability after 18 hours. Whereas four DN, CD1-restricted $T$ cell lines had no effect on the number of colony-forming units (CFUs) of virulent M. tuberculosis, both $\mathrm{CD}^{+} \mathrm{CD} 1$-restricted $\mathrm{T}$ cell lines examined reduced the number of CFUs by 35 to $50 \%$ (Fig. 4). In addition, two human influenza peptide-specific $\mathrm{CD}^{+}$CTL lines that cause lysis solely by a granuledependent mechanism reduced the number of viable mycobacteria by lysing infected macrophages that had been simultaneously pulsed with influenza peptide. Although the percentage reduction of CFUs was within an order of magnitude, M. tuberculosis infection in vivo is slow and protracted, and the time of in vitro assay was only 18 hours, so that a cumulative antimicrobial effect mediated by these $T$ cells over time could have a profound effect on the number of bacilli during the course of infection.

These data and a recent study of a murine model (15) suggest that the two de- fined mechanisms of cytotoxicity are associated with distinct phenotypic T cell subsets, yet have differential effects on microbial immunity. Consistent with the findings that Fas-FasL interactions appear to be most relevant to lysis of cells of the immune system itself, this mechanism may function primarily in immune regulation in vivo, particularly in eliminating antigen-expressing APCs, thereby down-regulating immune-mediated tissue injury (16). In contrast, the ability of $\mathrm{CD} 8^{+}$CTLs both to lyse infected cells by the granule-dependent mechanism and to kill intracellular M. tuberculosis suggests that they may have a special role in resistance to infectious

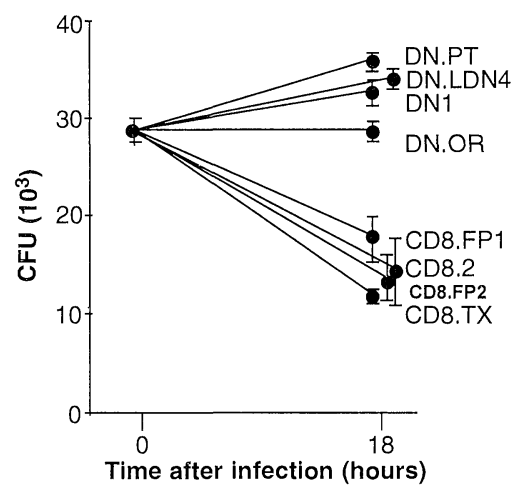

Fig. 4. Perforin, but not Fas-FasL-mediated lysis, inhibits the growth of $M$. tuberculosis. Macrophages infected with live $M$. tuberculosis were coincubated with DN or $\mathrm{CD}^{+} \mathrm{CTL}$ at an E:T ratio of 10:1. After 18 hours, cells were lysed with saponin to release intracellular bacteria. For the determination of mycobacterial viability, fivefold dilutions of the lysate were plated in duplicate on $7 \mathrm{H} 11$ agar plates. CFUs were counted after a 3-week incubation. The results shown are representative of two independent experiments. Error bars correspond to the SEM.

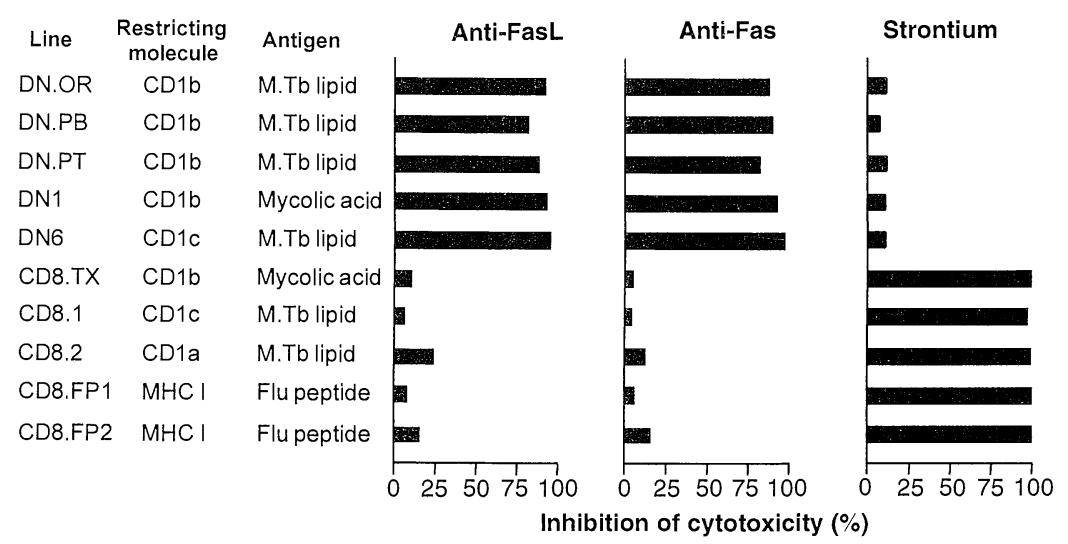

Fig. 3. Subset-dependent mechanisms of cytotoxicity. The ability of blocking antibodies to FasL or Fas and of $\mathrm{Sr}^{2+}$ to inhibit antigen-specific cytotoxicity of CD1- or MHC class I-restricted CTLs at an E:T ratio of 10:1 was determined. Inhibition of cytotoxicity was calculated as [(specific cytotoxicity in the absence of inhibitor - specific cytotoxicity in the presence of inhibitor)]/(specific cytotoxicity in the absence of inhibitor). pathogens. The finding in gene-disrupted mouse models that perforin is itself not essential for resolution of mycobacterial infection in vivo (17) raises the possibility that the antimicrobial activity may be independent of the lytic process or that there may be additional mediators in the cytotoxic granules, such as granzymes, defensins, or granulysin (18). Delineation of the mechanism whereby CD1-restricted CTLs kill intracellular mycobacteria may provide useful insights into mechanisms whereby other types of CTLs contribute to protection against microbial pathogens.

\section{REFERENCES AND NOTES}

1. J. L. Flynn, M. M. Goldstein, K. J. Triebold, B. Koller, B. R. Bloom, Proc. Natl. Acad. Sci. U.S.A. 89, 12013 (1992).

2. J. Turner and H. M. Dockrell, Immunology 87, 339 (1996); G. DeLibero, I. Flesch, S. H. E. Kaufmann, Eur. J. Immunol. 18, 59 (1988); R. E. Tascon et al. Nature Med. 2, 888 (1996).

3. E. M. Beckman, et al., Nature 372, 691 (1994).

4. P. A. Sieling, et al., Science 269, 227 (1995).

5. CD1-restricted $T$ cell lines were derived from the peripheral blood as follows: CD4, $\gamma \delta \mathrm{T}$ cells and, in some instances, CD8 T cells were subjected to immunomagnetic depletion and culture with $M$. tuberculosis extract $(10 \mu \mathrm{g} / \mathrm{ml}$ ) (supernatant of ultracentrifuged probe-sonicate of the virulent $M$. tuberculosis strain H37Rv) in the presence of peripheral blood mononuclear cells (PBMCs) treated with granulocyte-macrophage colony-stimulating factor (GMCSF) $(200 \mathrm{U} / \mathrm{ml}$; gift of Genetics Institute, Cambridge, MA) and interleukin-4 (IL-4, $100 \mathrm{U} / \mathrm{ml}$; gift of Schering-Plough, Kenilworth, NJ) to induce CD1 expression (6). All lines exclusively expressed the $\alpha \beta T$ cell receptor (TCR). Cell lines were maintained by biweekly stimulation with $M$. tuberculosis extract in the presence of heterologous CD1+ APCs. Monoclonal antibodies used for flow cytometry and blocking experiments were as follows (4): OKT6, which blocks CD1a; WM-25, which blocks CD1b; 10C3, which blocks CD1c; OKT4, which recognizes CD4; and OKT8, which recognizes CD8a; antibodies to $\alpha \beta$ TCR (Becton-Dickinson, San Jose, CA) and to $\gamma \delta$ TCR, LNK16, and CD16 (Serotec, Washington, DC).

6. S. Porcelli, C. T. Morita, M. B. Brenner, Nature $\mathbf{3 6 0}$ 593 (1992); J. P. Rosat, S. Porcelli, M. Brenner, unpublished results.

7. PBMCs from healthy donors were treated with GMCSF $(200 \mathrm{U} / \mathrm{ml})$ and $/ \mathrm{L}-4(100 \mathrm{U} / \mathrm{ml})$ for 72 hours. Nonadherent cells were discarded and the adherent fraction, which was enriched for $\mathrm{CD}^{+}{ }^{+}$cells $(50$ to $60 \%$ of the cells expressed CD1a, CD1b, and CD1c, as determined by flow cytometry), was detached by treatment with $1 \mathrm{mM}$ EDTA (Sigma) and replated in six-well plates at a density of $3 \times 10^{6}$ per well. Adherent monolayers were infected with live $M$. tuberculosis (virulent strain H37Rv) for 4 hours at a $\mathrm{MOI}$ of $5: 1$. Comparison of microscope counts of mycobacteria and their growth on Middlebrook $7 \mathrm{H} 11$ agar plates revealed a viability of the bacteria above $90 \%$. After extensive washing, macrophages were detached, and the efficiency of infection was determined by staining a sample with auramine-rhodamine $(3.77 \pm 0.32$ bacteria per cell, $83 \pm 4 \%$ of cells infected).

8. D. Kagi et al., Nature 369, 31 (1994); B. Lowin, M. Hahne, C. Mattmann, J. Tschopp, ibid. 370, 650 (1994); H. Kojima et al., Immunity 1, 357 (1994); C. M. Walsh et al., Proc. Natl. Acad. Sci. U.S.A. 91 10854 (1994).

9. P. A. Neighbour and H. S. Huberman, Y. Kress, Eur. J. Immunol. 12, 588 (1982); P. C. Quan, T. Ishizaka, B. R. Bloom, J. Immunol. 128, 1786 (1982); P. A Neighbour and H. S. Huberman, ibid., p. 1236.

10. $\mathrm{Sr}^{2+}$ was chosen as a selective inhibitor of granule- 
dependent lysis, because the calcium chelator EGTA, which blocks the perforin pathway, also inhibits up-regulation of FasL, as required in our studies with primary human $T$ cells.

11. Tumor necrosis factor- $\alpha($ TNF- $\alpha)$ induces lysis of a murine fibrosarcoma cell line independently of perforin or Fas-FasL (19). This cytokine did not contribute to lysis of the CTLs used in this study because addition of blocking antibody to TNF- $\alpha$ did not inhibit the cytotoxicity.

12. G. Berke, Annu. Rev. Immunol. 12, 735 (1994).

13. The $\mathrm{MHC}$ class I-restricted $\mathrm{CD} 8^{+} \mathrm{T}$ cell lines that specifically recognize a defined influenza virus matrix protein presented by human leukocyte antigen (HLA) A2 (CD8.FP1, CD8.FP2) were generated from the blood of healthy HLA A. $2^{+}$donors by stimulation of PBMCs with the peptide $(10 \mu \mathrm{g} / \mathrm{ml}$ ) (gift of Cytel, San Diego, CA) (20). Lines were maintained by weekly stimulation with the peptide, with irradiated autologous PBMCs as feeder cells. Before the experiments, $\mathrm{CD}^{+}$cells were enriched by immunomagnetic depletion of CD4 ${ }^{+} T$ cells and natural killer cells.

14. S. H. E. Kaufmann, Immunol. Today 9, 168 (1988).

15. K. Benihoud, D. Bonardelle, P. Bobe, N. Kiger, Eur. J. Immunol. 27, 415 (1997).

16. T. S. Griffith, T. Brunner, S. M. Fletcher, D. R. Green, T. A. Ferguson, Science 270, 1189 (1995); H. Yagita et al., Immunol. Rev. 146, 223 (1995).

17. P. Laochumroonvorapong et al. Infect. Immun. 65 , 127 (1997); A. Cooper, C. D'Souza, A. A. Frank, I. Orme, ibid., p. 1317; R. J. Mazzaccaro, J. Flynn, B. R. Bloom, unpublished results.

18. S. Pena et al, J. Immunol. 158, 2680 (1997); M Anderson et al., EMBO J. 14, 1615 (1995); Y. Miyakawa et al., Infect. Immun. 64, 926 (1996).

19. R. K. Lee, J. Spielman, D. Y. Zhao, K. J. Olsen, E. R. Podack, J. Immunol. 157, 1919 (1996); M. Y. Braun, B. Lowin, L. French, H. Acha-Orbea, J. Tschopp, J. Exp. Med. 183, 657 (1996).

20. A. J. McMichael, F. M. Gotch, J. Santos-Aguado, J. L. Strominger, Proc. Natl. Acad. Sci. U.S.A. 85 , 9194 (1988).

21. N. Kayagaki et al., J. Exp. Med. 182, 1777 (1995).

22. W. C. Liles, P. A. Kiener, J. A. Ledbetter, A. Aruffo, S. J. Klebanoff, ibid. 184, 429 (1996).

23. P. L. Coleman and G. D. Green, Methods Enzymol. 80, 408 (1981).

24. $C D 1^{+}$macrophages, which were infected with live $M$. tuberculosis, were labeled with $100 \mu \mathrm{Ci}$ of ${ }^{51} \mathrm{Cr}(\mathrm{ICN}$, Costa Mesa, CA) for 1 hour and plated in a 96-well $\checkmark$-bottom plate at a final concentration of 4000 targets per $100 \mu$ l. Appropriate samples were incubated with blocking antibodies to CD1a, CD1b, or CD1c for $30 \mathrm{~min}$ before addition of the T cells. After a 9-hour incubation, target cell lysis was calculated by quantifying ${ }^{51} \mathrm{Cr}$ release in a gamma-counter. The data are given as percent specific lysis, calculated as [(cpm release from experimental - cpm spontaneous release)/(maximal release $-\mathrm{cpm}$ spontaneous release) $\times 100$ ]. The spontaneous ${ }^{51} \mathrm{Cr}$ release by macrophages in the absence of $T$ cells was $<15 \%$.

25. $\mathrm{CD}^{+}{ }^{+}$macrophages were pulsed with soluble $M$. tuberculosis extract $(5 \mu \mathrm{g} / \mathrm{ml})$ overnight, detached with $1 \mathrm{mM}$ EDTA, and labeled with $100 \mu \mathrm{Ci}$ of ${ }^{51} \mathrm{Cr}$ for 1 hour. For inhibition of the interaction between FasL and Fas, the assay was done in the presence of blocking antibodies to FasL (21) (Pharmingen, San Diego, CA) or Fas (22) (Immunotech, Westbrook). Degranulation of the cytotoxic granules was induced by initial treatment of T cells with 25 $\mathrm{mM} \mathrm{Sr}{ }^{2+}$ (Aldrich, Milwaukee, WI) for 18 hours ${ }^{51} \mathrm{Cr}$ release was determined after a 4-hour incubation. Expression of Fas on the target cells was not affected by infection with $M$. tuberculosis, as determined by flow cytometry.

26. CTLs $\left(5 \times 10^{5}\right)$ were incubated in the presence of 25 $\mathrm{mM} \mathrm{Sr}{ }^{2+}$ for 10 hours in a final volume of $1.5 \mathrm{ml}$. The amount of $\mathrm{N} \alpha-\mathrm{CBZ}_{-}{ }_{-}$lysine thiobenzyl (BLT) -esterase in the supernatant was determined by the BLTesterase assay (23). The supernatants $(20 \mu l)$ were coincubated with $35 \mu \mathrm{l}$ of $1 \mathrm{mM} \mathrm{BLT}$ (Sigma), $35 \mu \mathrm{l}$

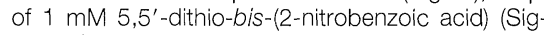
ma), and $10 \mu \mathrm{l}$ of a $0.1 \%$ Triton X-100 (Sigma) solution. After a 30 -min incubation at $37^{\circ} \mathrm{C}$, the absorbance at $405 \mathrm{~nm}$ was determined.
27. P. Chomczynski and N. Sacchi, Anal. Biochem. 162, 156 (1987).

28. FasL primer and probe sequences were designed as follows: FasL 5': CAGCTCTTCCACCTGCAGAAGG: FasL 3': AGATTCCTCAAAATTGATCAGAGAGAG; FasL probe: GAGCCGAGGAGTGTGGCCCATTTAACAGGG. PCR was performed with AmpliTaq polymerase $(0.5 \mathrm{U} / \mathrm{ml}$; Perkin-Elmer-Cetus) plus $2.5 \mathrm{mM}$ $\mathrm{MgCl}_{2}$ for $25 \mathrm{~s}$ of denaturation at $94^{\circ} \mathrm{C}$ followed by $45 \mathrm{~S}$ of annealing and extension at $65^{\circ} \mathrm{C}$ for $35 \mathrm{con}$ secutive cycles. PCR products were resolved by agarose gel electrophoresis and transferred to nylon membranes (Amersham, Arlington Heights, IL). The membranes were then probed with an internal oligonucleotide probe labeled at the $5^{\prime}$ end with $\gamma^{-{ }^{32} \mathrm{P}}$ and polynucleotide kinase (Boehringer Mannheim, Ger- many) and visualized by autoradiography.

29. E. P. Miskovsky et al., J. Immunol. 153, 2787 (1994)

30. We are indebted to M. Horwitz for use of his P3 laboratory and $P$. Sieling for continuous support and helpful discussions. Supported by the AIDS Stipendium; Deutsches Krebsforschungszentrum, Heidelberg (S.S.); $\mathrm{NIH}$ (R.L.M., S.A.P., B.R.B., M.B.B.); the Arthritis Foundation (S.A.P.); the Howard Hughes Medical Institute (B.R.B.); the Swiss Foundation for Grants in Medicine and Biology (J.-P.R); and the United Nations Development Programme-World Bank-World Health Organization Special Program for Research and Training in Tropical Diseases (IMMLEP) and the Dermatologic Research Foundation of California.

\title{
Multiple and Ancient Origins of the Domestic Dog
}

\author{
Carles Vilà, Peter Savolainen, Jesús E. Maldonado, \\ Isabel R. Amorim, John E. Rice, Rodney L. Honeycutt, \\ Keith A. Crandall, Joakim Lundeberg, Robert K. Wayne*
}

Mitochondrial DNA control region sequences were analyzed from 162 wolves at 27 localities worldwide and from 140 domestic dogs representing 67 breeds. Sequences from both dogs and wolves showed considerable diversity and supported the hypothesis that wolves were the ancestors of dogs. Most dog sequences belonged to a divergent monophyletic clade sharing no sequences with wolves. The sequence divergence within this clade suggested that dogs originated more than 100,000 years before the present. Associations of dog haplotypes with other wolf lineages indicated episodes of admixture between wolves and dogs. Repeated genetic exchange between dog and wolf populations may have been an important source of variation for artificial selection.

The archaeological record cannot resolve whether domestic dogs originated from a single wolf population or arose from multiple populations at different times $(1,2)$. However, circumstantial evidence suggests that dogs may have diverse origins (3). During most of the late Pleistocene, humans and wolves coexisted over a wide geographic area (1), providing ample opportunity for independent domestication events and continued genetic exchange between wolves and dogs. The extreme phenotypic diversity of dogs, even during the early stages of domestication $(1,3,4)$, also suggests a varied genetic heritage. Consequently, the genetic diversity of dogs may have been enriched by multiple founding events, possibly followed by occasional in-

C. Vilà, J. E. Maldonado, I. R. Amorim, R. K. Wayne, Department of Biology, University of California, Los An geles, CA 90095-1606, USA.

P. Savolainen and J. Lundeberg, Department of Biochemistry, Royal Institute of Technology, S 10044 Stockholm, Sweden.

J. E. Rice and R. L. Honeycutt, Faculty of Genetics and Department of Wildlife and Fisheries Sciences, Texas A\&M University, College Station, TX 77843, USA.

K. A. Crandall, Department of Zoology and M. L. Bean Museum, Brigham Young University, Provo, UT 84602, USA.

*To whom correspondence should be addressed. E-mail: rwayne@ucla.edu terbreeding with wild wolf populations.

We sequenced portions of the mitochondrial DNA of wolves and domestic dogs. Initially, 261 base pairs (bp) of the left domain of the mitochondrial control region (5) were sequenced from 140 dogs representing 67 breeds and five crossbreeds and 162 wolves representing 27 populations from throughout Europe, Asia, and North America (Fig. 1) (6). Because all wild species of the genus Canis can interbreed (7) and thus are potential ancestors of the domestic dog, five coyotes (Canis latrans) and two golden, two blackbacked, and eight Simien jackals (C. aureus, C. mesomelas, and $C$. simensis, respectively) were also sequenced.

The control region of wolves and dogs was highly polymorphic (Fig. 1). We found 27 wolf haplotypes that differed on average by $5.31 \pm 0.11$ ( $\pm \mathrm{SE}$ ) substitutions $(2.10 \pm 0.04 \%)$, with a maximum of 10 substitutions $(3.95 \%)$. The distribution of wolf haplotypes demonstrated geographic specificity, with most localities containing haplotypes unique to a particular region (Fig. 1). Four haplotypes (W2, W7, W14, and W22) had a widespread distribution. In dogs, 26 haplotypes were found. Only haplotype D6 also occurred in 